\title{
ELECTROCHEMICAL BEHAVIOR OF TANNIN SOLUTIONS UNDER MICROWAVE IRRADIATION
}

\author{
Jiacheng WU ${ }^{1,2}$, Li ZHANG ${ }^{1}$, Jinwei ZHANG ${ }^{1}$, Haibin GU ${ }^{1,2}$, Wuyong CHEN ${ }^{1,2 *}$ \\ 1Key Laboratory of Leather Chemistry and Engineering of Ministry of Education, Sichuan University, Chengdu 610065, P. R. \\ China
}

2National Engineering Laboratory for Clean Technology of Leather Manufacture, Sichuan University, Chengdu 610065,

P. R. China

Received: 16.01.2017

Accepted: 30.03.2017

https://doi.org/10.24264/Ifj.17.2.3

\section{ELECTROCHEMICAL BEHAVIOR OF TANNIN SOLUTIONS UNDER MICROWAVE IRRADIATION}

ABSTRACT. Vegetable tannin extract has an important use as a tanning agent in leather industry. The electrochemical behavior of tannin solutions, as a critical factor, greatly affect vegetable tanning. In this work, we have investigated the particle size, Zeta potential and conductivity of Commercial Acacia Mangium extract solutions (CAME) and Commercial valonia extract solutions (CVE) under water bath heating $(\mathrm{WBH})$ and microwave irradiation heating $(\mathrm{MIH})$. The heating conditions were selected as follows: time, $5 \mathrm{~min}, 15 \mathrm{~min}, 30 \mathrm{~min}, 60$ min and $120 \mathrm{~min}$; temperature, $30^{\circ} \mathrm{C}, 40^{\circ} \mathrm{C}$ and $50^{\circ} \mathrm{C}$. It was found that the particle size of both CAME and CVE decreased under MIH while Zeta potential increased compared with WBH. Furthermore, the features become more and more significant with the irradiation temperature and time. And the conductivity of CAME and CVE increased more with the temperature under MIH in comparison to WBH. As a result, in the condition of microwave irradiation, tannin extract can easily penetrate into skins and then crosslink well with the collagen owing to the small tannin particle size and stable solution system, hence microwave may contribute to the penetration of tannin extracts in the skin and the binding properties with collagen in vegetable tanning.

KEY WORDS: dynamic light scattering, electrochemical behavior, microwave irradiation, vegetable tannin extract

COMPORTAMENTUL ELECTROCHIMIC AL SOLUTIILOR DE TANIN SUPUSE IRADIEIRII CU MICROUNDE

REZUMAT. Extractul de tanin vegetal are o utilizare importantă ca agent de tăbăcire în industria pielăriei. Comportamentul electrochimic al soluţiilor de tanin, ca factor critic, afectează foarte mult tăbăcirea vegetală. În această lucrare s-au investigat mărimea particulelor, potenţialul Zeta şi conductivitatea soluţiilor pe bază de extract comercial de Acacia Mangium (CAME) şi extract comercial de vallonia (CVE) la încălzire în baie de apă (WBH) şi încălzire prin iradiere cu microunde (MIH). Condiţiile de încălzire au fost selectate după cum urmează: timp - 5 min, 15 min, $30 \mathrm{~min}, 60 \mathrm{~min}$ şi $120 \mathrm{~min}$; temperatură $-30^{\circ} \mathrm{C}, 40^{\circ} \mathrm{C}$ şi $50^{\circ} \mathrm{C}$. S-a constatat că atât mărimea particulelor de CAME cât şi a celor de CVE a scăzut sub MIH, în timp ce potenţialul Zeta a crescut în comparaţie cu WBH. În plus, caracteristicile devin din ce în ce mai semnificative odată cu temperatura şi timpul de iradiere. Conductivitatea CAME şi CVE a crescut mai mult odată cu temperatura sub MIH în comparaţie cu WBH. Ca urmare, în starea de iradiere cu microunde, extractul de tanin poate pătrunde cu uşurință în piele şi apoi se reticulează bine cu colagenul, datorită particulelor de tanin mici şi soluţiei stabile; aşadar microundele pot facilita penetrarea extractelor de tanin în piele şi pot îmbunătăţi proprietăţile de legare cu colagenul în tăbăcirea vegetală.

CUVINTE CHEIE: dispersie dinamică a luminii, comportament electrochimic, iradiere cu microunde, extract de tanin vegetal

LE COMPORTEMENT ÉLECTROCHIMIQUE DES SOLUTIONS DE TANNIN SOUS L'IRRADIATION DES MICRO-ONDES

RÉSUMÉ. L'extrait de tanin végétal a une utilisation importante en tant qu'agent de tannage dans l'industrie du cuir. Le comportement électrochimique des solutions de tanin, en tant que facteur critique, affecte grandement le tannage végétal. Dans cet article, on a étudié la granulométrie, le potentiel Zeta et la conductivité des solutions d'extrait commercial d'Acacia Mangium (CAME) et d'extrait commercial de vallonée (CVE) sous chauffage au bain-marie (WBH) et à l'irradiation par micro-ondes (MIH). Les conditions de chauffage ont été choisies comme suit: temps - $5 \mathrm{~min}, 15 \mathrm{~min}, 30 \mathrm{~min}, 60 \mathrm{~min}$ et $120 \mathrm{~min}$; température, $30^{\circ} \mathrm{C}, 40^{\circ} \mathrm{C}$ et $50^{\circ} \mathrm{C}$. On a constaté que la taille des particules de CAME et de CVE diminue sous MIH tandis que le potentiel Zeta augmente par rapport à WBH. En outre, les caractéristiques deviennent de plus en plus importantes avec la température et le temps d'irradiation. La conductivité de CAME et CVE augmente davantage avec la température sous MIH par rapport à WBH. En conséquence, dans l'état de l'irradiation par micro-ondes, l'extrait de tanin peut facilement pénétrer dans la peau et ensuite réticuler avec le collagène en raison de la petite taille des particules de tanin et du système de solution stable; par conséquent, les micro-ondes peuvent contribuer à la pénétration des extraits de tanin dans la peau et peuvent optimiser les propriétés de liaison avec le collagène dans le tannage végétal.

MOTS CLÉS: diffusion dynamique de la lumière, comportement électrochimique, irradiation par micro-ondes, extrait de tanin végétal

\section{INTRODUCTION}

Microwave is a kind of electromagnetic wave in the frequency from $300 \mathrm{MHz}$ to 300 $\mathrm{GHz}$. At present, the frequency of microwave equipment used in the industry is $2450 \mathrm{MHz}$ (wavelength, $0.122 \mathrm{~m}$ ) and $915 \mathrm{MHz}$ (wavelength, $0.33 \mathrm{~m}$ ). In general, the frequency of household microwave oven is $2450 \mathrm{MHz}$ [1]. Since microwave is a novel, mild, environmentally friendly and efficient thermal technology, it is widely used in pharmaceutical chemicals [2], food chemicals
$[3,4,5]$, life sciences field [6] and so on. And these applications have already achieved fruitful research results. However, little research on the application in leather-making was reported, especially the vegetable tanning, which is the aim of this work.

Vegetable tannin extracts have a very important position in leather-making, such as tanning and retanning procedures. With good knowledge of tannin extract, their solutions are extremely complex whether in physics or chemistry. From the composition point of

\footnotetext{
* Correspondence to: Wuyong CHEN, Key Laboratory of Leather Chemistry and Engineering of Ministry of Education, Sichuan University, Chengdu 610065, P. R. China, e-mail: wuyong.chen@163.com
} 
view, tannin extract is a complex mixture of polydisperse colloid, containing tannins, non tannins and insolubles. In chemistry, vegetable tannins are classified into two categories: hydrolysable tannin and condensed tannin. According to the reported research [7], condensed tannin shows different properties and features from hydrolysable tannin. Owing to a reversible equilibrium between the molecular dispersions and colloidal dispersions, tannin extract solution system is often referred to as semicolloid. And the micelle of vegetable tannin extracts is a structure with double electrical layer: adsorption layer directly connected with colloidal nucleus and diffusion layer outside the adsorption layer whereabout colloidal nucleus [8]. In electric field, when the tannin molecules move toward the anode, the positive ions in the adsorption layer move with the micelles and the positive ions in the diffusion layer are disengaged from the micelles. Meanwhile, the formed potential difference between micelles and the dispersion medium is called Zeta potential [9]. The smaller the colloidal particle size is, the greater the diffusion coefficient is. Therefore, the tannin particles diffuse easily with great diffusion coefficient and it is calculated by the formula (1) as follows [10]:

$$
D=\frac{\mathbb{R}}{6 \pi \eta \gamma L}
$$

In vegetable tanning, the penetration speed of tannin particles is closely related to the size of tannin particles, and small tannin particles are able to penetrate the skins easily. Perhaps, tannin extracts respond to the microwave, resulting in changes in the electrochemical behavior of the solution. According to Brownian motion, dynamic light scattering and electrophoresis properties of the colloid can be used to study the properties of colloidal particles, such as conductivity, Zeta potential and particle size distribution. And these properties are important for evaluating the permeability, filling performance and degree of combination between tannin extract and skin fibers, even beyond the chemical properties of the tannin extract solution itself [11]. In this work, we have investigated the electrochemical behavior of tannin extract solutions and evaluated the stability of the solutions under microwave irradiation. The penetration, filling and bonding performance of the tannin extract were explained, which may provide an experimental basis for revealing electrochemical change in the vegetable tanning.

\section{EXPERIMENTAL}

\section{Material}

Commercial Acacia Mangium extract (CAME) and Commercial valonia extract (CVE) were industrial products, commercially purchased from Wu Ming tannin extract factory in Guangxi, China. Microwave was produced by a Xian Yuhui MCR-3 microwave chemistry reactor. Zeta potential and particle size were measured on a Zetasizer Nano-ZS series equipment (Malvern Instruments, UK). Conductivities were performed on a DDS-307 conductivity meter (Shanghai INESA Scientific Instrument Co., Ltd, China).

\section{Methods}

Original tannin extract solutions (mass concentration, $4 \mathrm{~g} / \mathrm{L}$ ) were prepared according to procedure reported in the literature [12]. The solutions were centrifuged at $3000 \mathrm{r} / \mathrm{min}$ for 30 minutes and collected with a clean beaker.

The schematic diagram of the microwave reactor is displayed in Figure $1.60 \mathrm{~mL}$ of the solutions were heated in the condition of water bath and microwave irradiation, respectively. Selected conditions were showed as follows: time, $5 \mathrm{~min}, 15 \mathrm{~min}, 30 \mathrm{~min}, 60 \mathrm{~min}$ and $120 \mathrm{~min}$; temperature, $30^{\circ} \mathrm{C}, 40^{\circ} \mathrm{C}$ and $50^{\circ} \mathrm{C}$. After that, Zeta potential, particle size and conductivity of the treated solutions were measured, and then $\triangle$ AS (average size difference value between microwave irradiation heating and water bath heating) and $\triangle Z P$ (difference value of the absolute value about Zeta potential between microwave irradiation heating and water bath heating) were calculated. 


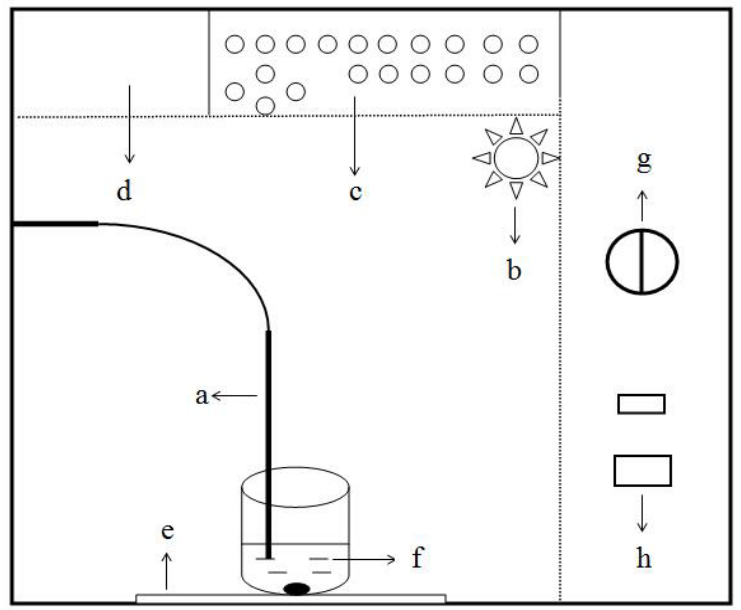

Figure 1. The schematic diagram of the microwave reactor

a: temperature sensor; b: microwave source; c: settings panel; $d$ : display; e: magnetic stirring stage; f: sample; g: magnetic stirring knobs; h: switch

\section{RESULTS AND DISCUSSION}

\section{Particle Size of CAME and CVE}

Known by Stokes-Einstein equation, hydrodynamic diameter of colloidal particles is proportional to the temperature, namely, rising temperature will increase colloidal particle size. Simultaneously, high temperature can accelerate Brownian motion of colloidal particles, and collisions appear more frequently among the particles. Thus, there is a substantial reduction in the stability of the solutions [13]. Nevertheless, in conventional heating process (water bath), thermal energy transfer to the external surface of material by convection, conduction and radiation in the existence of the thermal gradient so that the material is heated slowly and unevenly. But in microwave field, electromagnetic energy directly turns into thermal energy that can generate heat at different depths inside the materials, and the materials are heated more quickly and evenly [14]. Therefore, the average size of tannin extract may change somewhat under microwave irradiation.
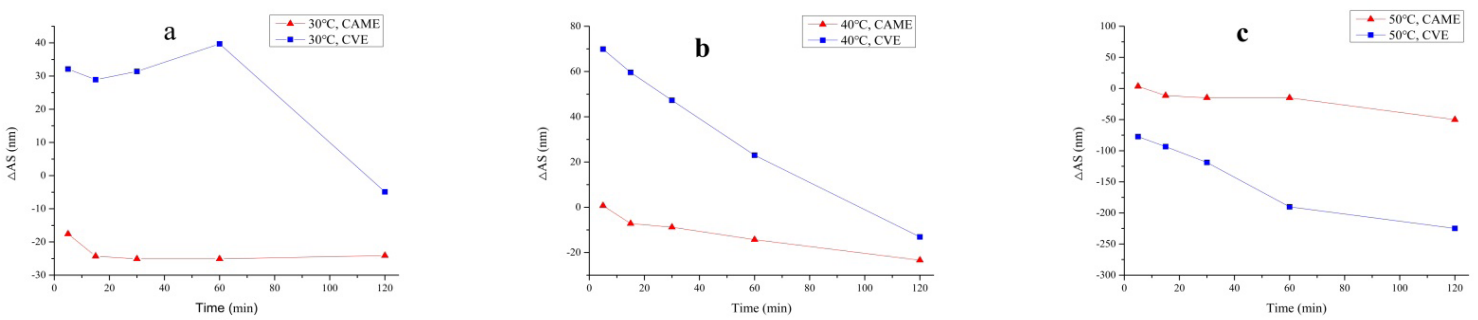

Figure 2. $\triangle A S$ of $C A M E$ and $C V E$ at $30^{\circ} \mathrm{C}(a), 40^{\circ} \mathrm{C}$ (b) and $50^{\circ} \mathrm{C}$ (c)

Figure 2 shows $\triangle \mathrm{AS}$ of the tannin extract solutions at different temperature $\left(30^{\circ} \mathrm{C}, 40^{\circ} \mathrm{C}\right.$ and $50^{\circ} \mathrm{C}$ ). Apparently, $\triangle \mathrm{AS}$ of CAME are all absolutely negative with time, namely, the average size decreased under microwave heating. At $30^{\circ} \mathrm{C}, \triangle \mathrm{AS}$ kept essentially unchanged with time while it decreased at $40^{\circ} \mathrm{C}$ and $50^{\circ} \mathrm{C}$. In terms of the level of $\triangle \mathrm{AS}$ for $\mathrm{CAME}$, microwave effect was more significant with longer heating time under a certain temperature. However, for $C V E$, there are both positive and negative terms of $\triangle A S$, so the average size increased or decreased as different heating temperature and time were carried out. There is a declining trend for $\triangle \mathrm{AS}$ of CVE even at different temperature. Obviously, at high temperature $\left(50^{\circ} \mathrm{C}\right)$, the particle size of CVE decreased dramatically with time under microwave heating. Contrast to $\triangle A S$ of CAME and CVE, different microwave effects occurred between them. For example, 
microwave irradiation induced the reduction of CAME particle size within 60 minutes under low temperature; but for CVE, it brought the increase of the particle size. However, the effect of microwave related to CAME and CVE particle size was a function of decrease in a similar vein under the high temperature. Although, there is a little different effect on hydrolysable tannin and condensed tannin under microwave irradiation, however, microwave may induce a reduction of tannin extract particle size to some extent.

\section{Zeta Potential of CAME and CVE}

Zeta potential is an important index to determine whether the colloidal solution is stable. In general, for a stable solution system, the absolute value of Zeta potential is more than $30 \mathrm{mV}$, on the contrary, the solution is an unstable system. When Zeta potential value is 0 , the solution arrives at the isoelectric point, and micelle aggregation and precipitation are most likely to occur.
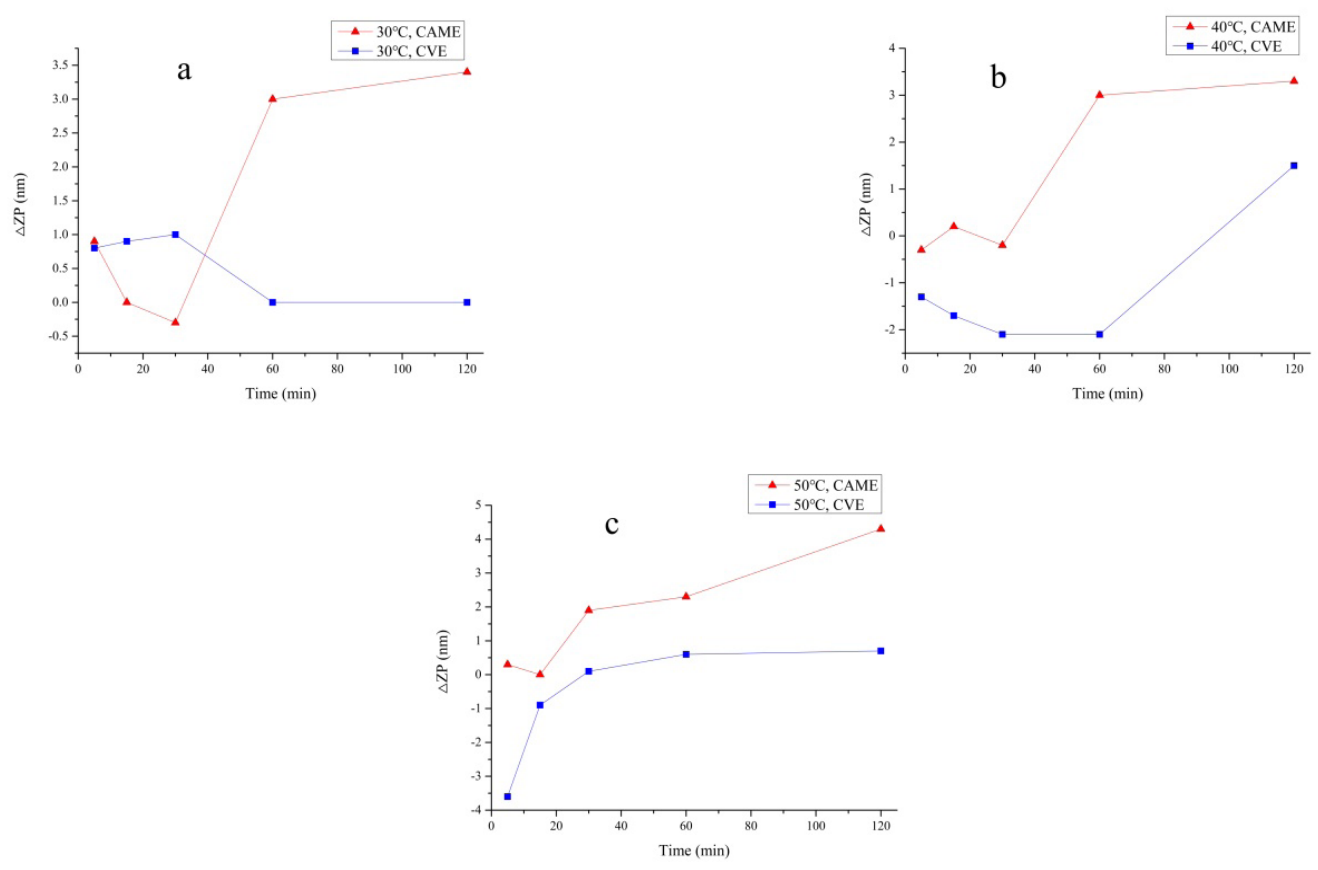

Figure 3. $\triangle \mathrm{ZP}$ of $\mathrm{CAME}$ and $\mathrm{CVE}$ at $30^{\circ} \mathrm{C}(\mathrm{a}), 40^{\circ} \mathrm{C}$ (b) and $50^{\circ} \mathrm{C}$ (c)

For the purpose of investigating the stability of tannin extract solutions under microwave irradiation, determination of Zeta potential about the solution was conducted. $\triangle \mathrm{ZP}$ of CAME and CVE at different temperature is exhibited in Figure 3. For CAME, although $\triangle \mathrm{ZP}$ decreases a little within 30 minutes, a rising tendency of $\triangle \mathrm{ZP}$ curve with time emerges visually at $30^{\circ} \mathrm{C}$, and it is the same when the temperature is $40^{\circ} \mathrm{C}$ and $50^{\circ} \mathrm{C}$. As the trend is relatively similar, there are some obvious differences about $\Delta \mathrm{ZP}$ between high and low temperature, as well as long and short time. For instance, when the solutions were heated for $120 \mathrm{~min}$ at $50^{\circ} \mathrm{C}$ (much more microwave function), $\triangle \mathrm{ZP}$ is $4.3 \mathrm{mV}$ which is the biggest different value of CAME in the measured data (seen in Figure 3c). Therefore, with more microwave function, the effect was more significant and promoted the stability of CAME better. As to CVE, $\triangle \mathrm{ZP}$ fluctuates around $0 \mathrm{mV}$ at $30^{\circ} \mathrm{C}$ (Figure $3 \mathrm{a}$ ), indicating that CVE did not respond well to microwave under the condition of low temperature. Even though $\triangle \mathrm{ZP}$ is negative before heating for 60 minutes, there is an obvious upward trend about $\triangle \mathrm{ZP}$ curve with time at $40^{\circ} \mathrm{C}$ and $50^{\circ} \mathrm{C}$ (Figure $3 \mathrm{~b}, 3 \mathrm{c}$ ). Apparently, $\Delta Z \mathrm{P}$ starts to increase when the time exceeds 30 minutes, hence a more stable solution may be in the treatment of microwave irradiation. As a result, the absolute value of Zeta potential of both CVE and CAME increases, and both of them show a more stable solution system under microwave irradiation. However, compared with CVE, there is an augment of $\triangle \mathrm{ZP}$ for CAME. Therefore, from 
the variation trend point of view, microwave irradiation is better for CAME to maintain a high degree of stability.

\section{Conductivities of CAME and CVE}

In order to study the electrolyte content in tannin extract solutions under microwave irradiation heating, the conductivity measurements were carried out. The results are presented in Table 1, where it can be seen that the conductivity always increases with time when the temperature is constant and it also increases with temperature when the time is fixed. However, it shows an increasing trend of the conductivity for both CAME and CVE at a low temperature level $\left(30^{\circ} \mathrm{C}\right)$ under microwave irradiation heating, but as temperature rises (especially at $50^{\circ} \mathrm{C}$ ), there is a little change between the two heating methods (microwave irradiation heating and water bath heating) in terms of conductivity. Since conductivity is proportional to electrolyte content which determined by the content of the materials dissociated from non tannins, it is obvious that the temperature plays a decisive role on electrolyte content dissociated from non tannins, nevertheless, microwave can promote the increase of the electrolyte content at the low temperature level.

Table 1: The conductivities of tannin extract solutions under MIH and WBH

\begin{tabular}{|c|c|c|c|c|c|c|c|}
\hline \multirow{2}{*}{$\begin{array}{l}\text { Tannin } \\
\text { extract }\end{array}$} & \multirow{2}{*}{ Temperature $\left({ }^{\circ} \mathrm{C}\right)$} & \multirow{2}{*}{$\begin{array}{l}\text { Heating } \\
\text { methods }\end{array}$} & \multicolumn{5}{|c|}{ Conductivities $(\mu \mathrm{S} / \mathrm{cm})$} \\
\hline & & & $5 \mathrm{~min}$ & $15 \mathrm{~min}$ & $30 \mathrm{~min}$ & $60 \mathrm{~min}$ & $120 \mathrm{~min}$ \\
\hline \multirow{6}{*}{ CAME } & \multirow{2}{*}{30} & $\mathrm{MIH}$ & 0.757 & 0.756 & 0.755 & 0.763 & 0.807 \\
\hline & & WBH & 0.746 & 0.748 & 0.752 & 0.758 & 0.767 \\
\hline & \multirow{2}{*}{40} & $\mathrm{MIH}$ & 0.867 & 0.877 & 0.894 & 0.931 & 1.010 \\
\hline & & WBH & 0.868 & 0.875 & 0.876 & 0.892 & 0.914 \\
\hline & \multirow{2}{*}{50} & $\mathrm{MIH}$ & 0.957 & 0.980 & 1.000 & 1.000 & 1.02 \\
\hline & & WBH & 0.934 & 0.975 & 0.994 & 1.000 & 1.02 \\
\hline \multirow{6}{*}{ CVE } & \multirow{2}{*}{30} & $\mathrm{MIH}$ & 0.535 & 0.549 & 0.552 & 0.566 & 0.575 \\
\hline & & WBH & 0.541 & 0.550 & 0.550 & 0.551 & 0.559 \\
\hline & \multirow{2}{*}{40} & $\mathrm{MIH}$ & 0.616 & 0.621 & 0.639 & 0.655 & 0.686 \\
\hline & & WBH & 0.615 & 0.618 & 0.632 & 0.635 & 0.642 \\
\hline & \multirow{2}{*}{50} & $\mathrm{MIH}$ & 0.656 & 0.655 & 0.673 & 0.695 & 0.702 \\
\hline & & WBH & 0.661 & 0.660 & 0.670 & 0.683 & 0.697 \\
\hline
\end{tabular}

$\mathrm{MIH}$ : microwave irradiation heating; $\mathrm{WBH}$ : water bath heating

\section{CONCLUSIONS}

In this work, the electrochemical behavior of vegetable tannin extract solution under microwave irradiation was investigated and characterized by the particle size, Zeta potential and conductivity. The results are showed as follows: (1) There is a different effect on hydrolysable tannin and condensed tannin under microwave irradiation, however, microwave induces a reduction of tannin extract particle size. Moreover, the effect is more significant with high irradiation temperature and long irradiation time. (2) The absolute value of Zeta potential of both CVE and CAME increases, indicating a more stable tannin extract solution under microwave irradiation. However, the microwave effect on hydrolysable tannin and condensed tannin is different, and it is better for CAME to maintain a high degree of stability. (3) Microwave irradiation can promote the increase of electrolyte content at a low temperature level. In conclusion, as a novel and efficient thermal method, microwave irradiation is likely to bring about reduction in the particle size, increase in conductivity and the absolute value of Zeta potential of tannin solutions. Therefore, microwave may contribute to the penetration of tannin extracts in the skin and the binding properties with collagen in vegetable tanning.

\section{Acknowledgements}

This work is financially supported by the National Natural Science Foundation of China (No. 21576171) and the Specialized Research 
Fund for the Doctoral Program of Higher Education (No. 20130181130009).

\section{REFERENCES}

1. Jin, Q.H., Dai, S.S., Huang, K.M., Microwave Chemistry, Science Press, Beijing, 1999, 7-14.

2. Meng, T., Wang, J., Peng, H.L., Fang, G.H., Li, M., Xiong, B., Xie, X., Zhang, Y.L., Wang, X., Shen, J.K., Discovery of Benzhydrylpiperazine Derivatives as CB1 Receptor Inverse Agonists via Privileged Structure-based Approach, Eur J Med Chem, 2010, 45, 3, 1133-1139, https:// doi.org/10.1016/j.ejmech.2009.12.018.

3. Kim, T.H., Choi, J.H., Choi, Y.S., Kim, H.Y., Kim, S.Y., Kim, H.W., Kim, C.J., Physicochemical Properties of Thawed Chicken Breast as Affected by Microwave Power Levels, Food Sci Biotechnol, 2011, 20, 4, 54-64, https://doi. org/10.1007/s10068-011-0134-2.

4. Barba, A.A., Calabretti, A., d'Amore, M., Piccinelli, A.L., Rastrelli, L., Phenolic Constituents Levels in Cv. Agria Potato under Microwave Processing, LWT Food Sci Technol, 2008, 41, 10, 1919-1926, https://doi. org/10.1016/j.lwt.2008.02.004.

5. Zhang, G.W., Hu, M.M., He, L., Fu, P., Wang, L., Zhou, J., Optimization of Microwaveassisted Enzymatic Extraction of Polyphenols from Waste Peanut Shells and Evaluation of its Antioxidant and Antibacterial Activities in vitro, Food Bioprod Process, 2013, 91, 2, 158-168, https://doi.org/10.1016/j. fbp.2012.09.003.

6. Panagopoulos, D.J., Effect of Microwave Exposure on the Ovarian Development of Drosophila melanogaster, Cell Biochem Biophys, 2012, 63, 2, 121-132, https://doi. org/10.1007/s12013-012-9347-0.
7. Zhang, L.L., Wang, Y.M., Xu, M., Wu, D.M., Chen, J.H., Research Process in Analytical Method of Vegetable Tannins, Chemistry and Industry of Forest Products, 2012, 32, 3, 107116.

8. Chen, W.Y., Li, G.Y., Tanning Chemistry, the Third Edition, China Light Industry Press, Beijing, 2011, 135-137.

9. Chen, J.P., Gong, Y., Chen, W.Y., Dynamic Light Scattering and Electrophoresis Studies of Stability of Tannin Extract Solutions, Chemistry and Industry of Forest Products, 2007, 27, 1, 19-24.

10. Zhou, L., Physical Chemistry Course, Science Press, Beijing, 2002, 279-280.

11. Thorstensen, T.C., Practical Leather Technology, Krieger Publishing Co, Malabar, Florida, 1985, 136-157.

12. Nanjing Technological College of Forest Products, The Forest Chemical Industry Manual (I), China Forestry Publishing House, Beijing, 1980.

13. Shi, B., Di, Y., The Application of Plant Polyphenol in Leather Industry, Leather Chemistry and Engineering, 1998, 8, 3, 5-25.

14. Fu, X.C., Shen, W.X., Yao, T.Y., Physical Chemistry, Higher Education Press, Beijing, 1990.

(C) 2017 by the author(s). Published by INCDTPICPI, Bucharest, RO. This is an open access article distributed under the terms and conditions of the Creative Commons Attribution license (http://creativecommons.org/licenses/by/4.0/). 